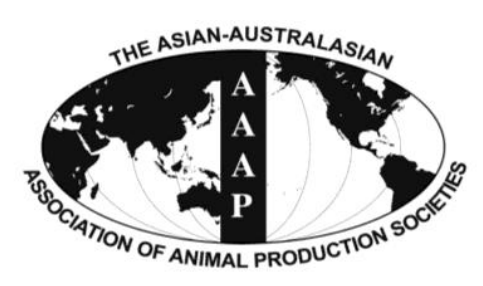

Open Access

Asian Australas. J. Anim. Sci.

Vol. 27, No. 10 : 1436-1442 October 2014

http://dx.doi.org/10.5713/ajas.2014.14095

\title{
Moisture Concentration Variation of Silages Produced on Commercial Farms in the South-Central USA
}

\author{
K. J. Han*, W. D. Pitman ${ }^{1}$, and A. Chapple ${ }^{2}$ \\ Louisiana State University Agricultural Center, School of Plant, Environmental, and Soil Sciences, \\ Baton Rouge, LA 70803 USA
}

\begin{abstract}
Preservation of forage crops as silage offers opportunity to avoid the high risk of rain-damaged hay in the humid southcentral USA. Recent developments with baled silage or baleage make silage a less expensive option than typical chopped silage. Silage has been important in the region primarily for dairy production, but baleage has become an option for the more extensive beef cattle industry in the region. Silage samples submitted to the Louisiana State University Agricultural Center Forage Quality Lab from 2006 through 2013 were assessed for dry matter (DM) and forage nutritive characteristics of chopped silage and baleage of the different forage types from commercial farms primarily in Louisiana and Mississippi. Of the 1,308 silage samples submitted, 1,065 were annual ryegrass (AR) with small grains (SG), the warm-season annual (WA) grasses, sorghums and pearl millet, and the warm-season perennial (WP) grasses, bermudagrass and bahiagrass, providing the remaining samples. Concentration of DM was used to indicate an effective ensiling opportunity, and AR silage was more frequently within the target DM range than was the WA forage group. The AR samples also indicated a high-quality forage with average crude protein (CP) of $130 \mathrm{~g} / \mathrm{kg}$ and total digestible nutrient (TDN) near $600 \mathrm{~g} / \mathrm{kg}$. The cooler winter weather at harvest apparently complicated harvest of SG silage with chopped SG silage lower in both CP and TDN (104 and $553 \mathrm{~g} / \mathrm{kg}$, respectively) than either AR silage or baleage of SG (137 and $624 \mathrm{~g} / \mathrm{kg}$ for CP and TDN, respectively). The hot, humid summer weather along with large stems and large forage quantities of the WA grasses and the inherently higher fiber concentration of WP grasses at harvest stage indicate that preservation of these forage types as silage will be challenging, although successful commercial silage samples of each forage type and preservation approach were included among samples of silages produced in the region. (Key Words: Baleage, Chopped Silage, Commercial Farm, Nutritive Value, Silage Moisture)
\end{abstract}

\section{INTRODUCTION}

In the south-central USA, hay has been the most widely used method of storing forage. Chopped silage has been a less widely used approach primarily restricted to dairy production. Rather recent availability of low-cost technology for storage of forage as baled silage or baleage provides livestock producers an option with reduced risk of rain damage compared to hay production in this high

\footnotetext{
* Corresponding Author: K. J. Han. Tel: +1-985-839-2322, Fax: +1-985-839-3202, E-mail: Khan@agcenter.lsu.edu

${ }^{1}$ Louisiana State University Agricultural Center, Hill Farm Research Station, Homer, LA 71040, USA.

2 Louisiana State University Agricultural Center, Dept. of Experimental Statistics, Baton Rouge, LA 70803, USA.

Submitted Feb. 11, 2014; Revised Apr. 10, 2014; Accepted Apr. 14, 2014
}

rainfall climate. Forage preservation as hay requires drying forage to moisture concentrations below $200 \mathrm{~g} / \mathrm{kg}$, which is necessary to prevent microbial spoilage. However, drying forage of a large biomass to this dry matter (DM) concentration is challenging because of high humidity and frequent rain in the US south-central region. Forage preservation as silage requires much shorter field curing time than hay because silage fermentation requires moisture in the pre-preserved forage. Therefore, silage or baleage is frequently suggested as an alternative to hay for forage preservation. It is not new information that moisture or DM concentration in forage greatly determines lactic acid fermentation of silage (Moisio and Heikonen, 1994). Unlike hay, silage preservation may require wilting rather than drying to achieve ideal lactic acid fermentation conditions. Depending on silage type, desired moisture concentration 
ranges vary slightly. Silage has several variations in preservation type including chopped silage, haylage, and baleage. Although deteriorated feed value due to seepage from low DM silage was addressed in the early 1960's (Gordon et al., 1965; Miller et al., 1965), subsequent evaluation of silage samples from ten commercial farms in Scotland indicated large variation in silage DM ranging from 161 to $480 \mathrm{~g} / \mathrm{kg}$ (Henderson et al., 1979). A more recent study indicated that the mean DM concentration in silage produced on Irish farms fell within the optimum DM range for lactic acid fermentation (averaged $349 \mathrm{~g} / \mathrm{kg}$ ), however, the range of DM concentration was still broad extending from 157 to $665 \mathrm{~g} / \mathrm{kg}$ (O’Brien et al., 2007). Such ranges in silage $\mathrm{DM}$ for areas with a history of silage production indicate that attaining target silage DM could be particularly difficult for farmers where the approach is somewhat new or evolving, forage species are diverse, and ensiling climate is highly variable.

Both rate and extent of silage fermentation are affected by forage DM concentration at the time of ensiling (Muck and Kung, 2007). The minimum DM concentration for effective lactic acid fermentation of chopped cool-season grass silage was identified as around $260 \mathrm{~g} / \mathrm{kg}$ on commercial farms in the UK (Haigh, 1990). Forage of higher DM concentration requires less fermentation to develop an anaerobically stable silage (Muck and Kung, 2007). Excessively dry silage can heat and spoil, while excessively wet silage can lose nutrients through effluent seepage or even undergo undesirable clostridial fermentation. Van Soest (1982) suggested that silages with greater than $300 \mathrm{~g} \mathrm{DM} / \mathrm{kg}$ were generally more palatable with higher intakes than were wetter silages, although heat damage and mold, which can reduce palatability and intake, are increasing risks with excessively high DM levels. Collins and Owens (2003) recommended that silage should be at least $300 \mathrm{~g} \mathrm{DM} / \mathrm{kg}$. Van Soest (1982) suggested that baled silage stability can be maximized with DM levels of 400 to $500 \mathrm{~g} / \mathrm{kg}$. Muck and Shinners (2001) noted that baleage does not ferment as well as chopped silage and should be 5 to 10 percentage units higher in DM to prevent clostridial fermentation. Silage preservation of forage with DM greater than the optimum range can produce weak fermentation due to lack of moisture for active fermentation or even aerobic deterioration. Low moisture concentration in forage can result in mold covered baled grass silage (O’Brien et al., 2007), however, for the humid Florida climate, Hersom and Kunkle (2011) indicated that $350 \mathrm{~g}$ $\mathrm{DM} / \mathrm{kg}$ or higher provided acceptable preservation. Suitable DM for baled silage was suggested by McCormick (2013) to be within the range of 400 to $600 \mathrm{~g} / \mathrm{kg}$, with preservation dependent on low moisture and anaerobic conditions rather than the silage acids as with more moist silages. Wilting bermudagrass to at least $400 \mathrm{~g} \mathrm{DM} / \mathrm{kg}$ improved fermentation characteristics and DM recovery in Florida evaluations (Bates et al., 1989). For the grasses often preserved as silage, with typically low levels of soluble carbohydrates to support lactic acid fermentation, and the climatic conditions of the south-central region, we identified a DM range of 350 to $550 \mathrm{~g} / \mathrm{kg}$ as an appropriate target DM range to encompass both chopped and baled silage. Due to lower moisture requirements often requiring extended drying time and vulnerability to aerobic deterioration, round bale silage requires a more careful wilting process than is typical for chopped silage to meet the desirable DM range (Huhnke et al., 1997).

Both cool-season and warm-season forages are produced in the south-central USA providing a range of conditions and challenges for silage production. Concentrations of soluble sugars to support silage fermentation differ among grass types, maturity, and environmental conditions (Muck and Kung, 2007). Coolseason grasses generally contain more soluble sugars for fermentation than do warm-season grasses (Muck and Kung, 2007), although sorghum ensiled near maturity has sufficient carbohydrates for fermentation at the typical DM levels of 300 to $400 \mathrm{~g} / \mathrm{kg}$. Both ensiling environment and forage characteristics differ for the cool- and warm-season species. A forage testing program for producer samples primarily from Louisiana and Mississippi has provided a data set of silage moisture and resulting measures of forage nutritive value of a variety of grass species as either chopped silage or baleage. The forage quality analyses provided were developed primarily for evaluation of feeding value of hay for ruminant livestock. While the fiber analyses used can provide useful information for silage, effects of ensiling processes, particularly outside the optimal DM range, may affect the usefulness of standard crude protein values. This study was conducted to evaluate the range in DM concentration of commercial silage and assess possible associations of forage nutritive value with DM, forage type, and silage preparation method of seasonally produced silage by commercial farms in the south-central USA.

\section{MATERIALS AND METHODS}

\section{Sample collection and analysis}

Forage samples produced mostly from commercial farms in Louisiana, Mississippi, and also some neighboring states were submitted to the Louisiana State University Agricultural Center Forage Quality Lab in sealed plastic bags for analysis of forage nutritive value. These samples were analyzed for DM concentration, crude protein (CP), acid detergent fiber (ADF), neutral detergent fiber (NDF), and total digestible nutrients (TDN). Samples submitted as silage between 2006 and 2013 were separated and 
categorized based on forage type and silage preparation (Table 1). Silage samples submitted as forage sorghum, sudangrass, sorghum $\times$ sudangrass hybrids, and pearl millet were categorized as warm-season annual (WA) grasses. These forage crops, especially the emerging low lignin brown midrib (BMR) type forage sorghums, are rapidly being accepted by commercial dairy farms. The base forages in the south-central region, bermudagrass and bahiagrass, were grouped as warm-season perennial (WP) grasses. Cool-season perennial grasses are not widely grown in the region and were not among the silage products received. Cool-season silages submitted were primarily annual ryegrass (AR) with some small grain (SG).

Upon arrival at the Forage Quality Lab, samples were weighed and dried at $55^{\circ} \mathrm{C}$ for 72 hours to determine DM concentration as received. The dried samples were ground with a Wiley mill equipped with a 1-mm screen. Samples were scanned using near infrared reflectance spectroscopy (Mod. 6500, Foss NIRSystem, Inc., Silver Spring, MD, USA) and assessed for ADF, NDF, and TDN with locally developed equations for each component. When results for an individual sample extended beyond the normal standard deviation range for a given species, the sample was analyzed using wet chemistry for determination of the nutrient values. Analysis of ADF, NDF, and TDN was by procedures of Van Soest and Robertson (1980). Crude protein was estimated as 6.25 times the percentage of $\mathrm{N}$ determined using the semimicro-Kjeldahl procedure of Bremner and Breitenbeck (1983).

\section{Statistical analysis}

The residual plot for DM, CP, and TDN did not follow normal distributions, therefore these variables were natural $\log$ transformed for statistical analysis, which made the model residuals conform to the assumption of normality. Statistical procedures for a factorial arrangement of completely randomized design were used to analyze impact of four forage types and two silage preparations on silage DM, CP, ADF, NDF, and TDN. Statistical analysis was conducted with the mixed model procedure of SAS 9.3 Procedures Guide (SAS Institute, 2011). The four forage types, two silage preparations, and the interaction between forage type and silage preparation were considered as fixed effects. Production year and sample entry were considered as random effects but were included as part of the model residual rather than treated as separate sources of variation. Pearson correlations were obtained for nutrient and DM responses using correlation procedures of SAS software. Observations within the target DM concentration (350 to $550 \mathrm{~g} / \mathrm{kg}$ ) were labeled as " 1 " to indicate a success and observations out of the target DM concentration were labeled as "0". Proc Glimmix was used to determine if forage type or silage preparation affected the probability of DM being in the target region by treating target DM as a binomial random variable. Treatment means were compared using pairwise comparisons.

\section{RESULTS}

As suggested by sample numbers (Table 1), AR has been the most frequently ensiled forage in the region with baleage being the most common silage preparation approach in recent years. Sample numbers indicate that chopped silage remains an important preservation method for AR and is a continuing approach for WA forages. Only limited numbers of chopped silage samples of the other forage types were received. Both forage type and silage preparation along with their interaction contributed significantly to differences in DM and nutritive value of the silages evaluated (Table 2). Characterization of DM and measures of nutritive value (Table 3 ) indicate some general differences among the forage types and silage preparations. The numeric mean of DM concentration of WA forage was lower than the other silages. Baleages of WA grasses and AR had substantially higher DM than did chopped silage of these forage types, while DM of SG baleage was only slightly, but not significantly ( $p>0.05)$, higher than that of SG chopped silage. Chopped silage of WP grasses was

Table 1. Commercially produced silage classified by forage type and silage preparation

\begin{tabular}{|c|c|c|c|c|}
\hline \multirow[t]{2}{*}{ Forage type } & \multirow[t]{2}{*}{ Species } & \multirow[t]{2}{*}{ Common name } & \multicolumn{2}{|c|}{$\begin{array}{c}\text { Number of entry by silage } \\
\text { preparation }{ }^{1}\end{array}$} \\
\hline & & & Chopped silage & Baleage \\
\hline Warm-season annual grass & $\begin{array}{l}\text { Sorghum bicolor, } \\
\text { Pennisetum glaucum }\end{array}$ & $\begin{array}{l}\text { Forage sorghum, } \\
\text { Sudangrass, } \\
\text { Sorghum } \times \text { sudangrass hybrids } \\
\text { Pearl millet }\end{array}$ & 86 & 54 \\
\hline Warm-season perennial grass & $\begin{array}{l}\text { Cynodon dactylon, } \\
\text { Paspalum notatum }\end{array}$ & $\begin{array}{l}\text { Bermudagrass } \\
\text { Bahiagrass }\end{array}$ & 21 & 65 \\
\hline Annual ryegrass & Lolium multiflorum & Annual ryegrass & 266 & 799 \\
\hline Small grain & $\begin{array}{l}\text { Triticum aestivum, } \\
\text { Avena sativa, } \\
\text { Secale cereale }\end{array}$ & $\begin{array}{l}\text { Wheat } \\
\text { Oat } \\
\text { Cereal rye }\end{array}$ & 4 & 13 \\
\hline
\end{tabular}

${ }^{1}$ Forage sample as identified by producers. 
Table 2. Effect of forage types and silage preparation on the nutrient value of commercially produced silages

\begin{tabular}{lccccc}
\hline & $\mathrm{DM}$ & $\mathrm{CP}$ & $\mathrm{ADF}$ & $\mathrm{NDF}$ & $\mathrm{TDN}$ \\
\hline Forage type (FT) & $* * *$ & $* * *$ & $* * *$ & $* * *$ & $* * *$ \\
Silage preparation (SP) & $* * *$ & $* * *$ & $* * *$ & $\mathrm{~ns}$ & $* * *$ \\
$\mathrm{FT} \times \mathrm{SP}$ & $* * *$ & $*$ & $* * *$ & $* * *$ & $* * *$
\end{tabular}

DM, dry matter; CP, crude protein; ADF, acid detergent fiber; NDF, neutral detergent fiber; TDN, total digestible nutrient; ns, no significant.

higher in DM than the baleage of this forage type. The large standard deviation for DM of SG silage reflects a greater range in DM and particularly the low sample numbers for this forage type compared to the others. Also, DM was more variable within each forage type than were the measures of nutritive value. The WP grasses were higher in both ADF and NDF than the other forages, except for chopped SG silage. The AR was higher in CP and TDN than the other forages, except for SG baleage.

The probability that a silage product would fall within the target DM range of 350 to $550 \mathrm{~g} / \mathrm{kg}$ was affected by the forage type but not by the silage preparation (Table 4). The AR silage more frequently attained the target DM range than did WA silage (Table 5). The WP and SG silages were intermediate and not different from the other forage types (Table 5). Silages of both the WA and SG forage types were more frequently below the target DM range than were the other forage types (Figure 1). Although the frequency for non-target DM approached 0.5 for WP silage, this was about equally divided between excessive and insufficient DM levels and provided a higher frequency for excessive DM than obtained with AR or WA forage types. Frequency of non-target DM for AR silage was low and split between high and low DM. Although frequently below target DM, excessive DM was also an occasional problem with SG
Table 5. Contrasts of probability that forage type, warm-season annual grass (WA), warm-season perennial grass (WP), annual ryegrass (AR), and small grain (SG), contributed to attaining the target dry matter range (350 to $550 \mathrm{~g} / \mathrm{kg}$ ) of commercially produced silages

\begin{tabular}{lcccc}
\hline $\begin{array}{l}\text { Contrast forage } \\
\text { vs forage }\end{array}$ & Estimate & SE & DF & p value \\
\hline WA vs WP & 0.605 & 0.318 & 1300 & 0.055 \\
WA vs AR & 0.715 & 0.201 & 1300 & $<0.001$ \\
WA vs SG & 1.023 & 0.671 & 1300 & 0.127 \\
WP vs AR & 0.110 & 0.268 & 1300 & 0.682 \\
WP vs SG & 0.418 & 0.693 & 1300 & 0.547 \\
AR vs SG & 0.308 & 0.648 & 1300 & 0.635 \\
\hline
\end{tabular}

$\mathrm{SE}$, standard error; DF, degree of freedom.

silage.

Positive correlations were obtained between DM and TDN of WA $(\mathrm{p}<0.05)$ and AR $(\mathrm{p}<0.0001)$ indicating that increased DM resulted in a silage with higher nutrient concentration for these two forage types (Table 6). The only other measures of nutritive value correlated with DM were highly significant $(\mathrm{p}<0.0001)$ negative correlations of both $\mathrm{CP}$ and ADF of AR silage. The ADF and NDF were highly positively correlated $(p<0.0001)$, and each of these fiber values was highly negatively correlated $(\mathrm{p}<0.0001)$ with TDN for each forage type. Highly significant $(\mathrm{p}<0.0001)$ negative correlations were obtained between $\mathrm{CP}$ and both $\mathrm{ADF}$ and NDF of WP and AR silages.

\section{DISCUSSION}

The lower DM of WA silages than of silages of the other forage types reflects the combination of large stems which dry slowly, frequent high summer humidity which can limit

Table 3. Numerical mean of nutritive values in commercially produced warm-season annual grass (WA), warm-season perennial grass (WP), annual ryegrass (AR), and small grain (SG) silages

\begin{tabular}{|c|c|c|c|c|c|c|c|c|}
\hline \multirow{2}{*}{ Nutrient } & \multicolumn{2}{|c|}{ WA } & \multicolumn{2}{|l|}{ WP } & \multicolumn{2}{|l|}{$\mathrm{AR}$} & \multicolumn{2}{|l|}{ SG } \\
\hline & Chopped silage & Baleage & Chopped silage & Baleage & Chopped silage & Baleage & Chopped silage & Baleage \\
\hline & & & & & $\overline{\mathrm{DM}}$ & 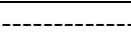 & 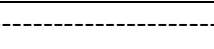 & \\
\hline DM & $275 \pm 14.9$ & $388 \pm 17.9$ & $511 \pm 19.5$ & $467 \pm 14.1$ & $396 \pm 10.0$ & $457 \pm 8.2$ & $406 \pm 61.1$ & $422 \pm 34.5$ \\
\hline $\mathrm{CP}$ & $95 \pm 4.3$ & $117 \pm 5.2$ & $94 \pm 5.7$ & $106 \pm 4.1$ & $130 \pm 2.8$ & $131 \pm 2.3$ & $104 \pm 17.9$ & $137 \pm 10.1$ \\
\hline $\mathrm{ADF}$ & $368 \pm 5.9$ & $398 \pm 7.2$ & $425 \pm 7.8$ & $410 \pm 5.5$ & $385 \pm 3.8$ & $357 \pm 2.9$ & $428 \pm 25.0$ & $355 \pm 14.0$ \\
\hline NDF & $590 \pm 8.6$ & $643 \pm 10.5$ & $700 \pm 11.5$ & $715 \pm 8.1$ & $586 \pm 5.3$ & $562 \pm 3.9$ & $673 \pm 37.5$ & $546 \pm 30.0$ \\
\hline TDN & $522 \pm 6.6$ & $479 \pm 8.0$ & $500 \pm 8.7$ & $514 \pm 6.3$ & $598 \pm 4.4$ & $621 \pm 3.6$ & $553 \pm 27.3$ & $624 \pm 15.4$ \\
\hline
\end{tabular}

DM, dry matter; CP, crude protein; ADF, acid detergent fiber; NDF, neutral detergent fiber; TDN, total digestible nutrient.

Table 4. Probability that forage type and silage preparation contribute to attaining the target dry matter range ( $350 \mathrm{go} 550 \mathrm{~g} / \mathrm{kg})$ of commercially produced silages

\begin{tabular}{lcccc}
\hline Effect & Num DF & Den DF & F value & p value \\
\hline Forage type (FT) & 3 & 1300 & 4.34 & 0.0047 \\
Silage preparation (SP) & 1 & 1300 & 0.84 & 0.3600 \\
FT $\times$ SP & 3 & 1300 & 1.65 & 0.1756 \\
\hline
\end{tabular}

Num DF, numerator degree of freedom; Den DF, denominator degree of freedom. 


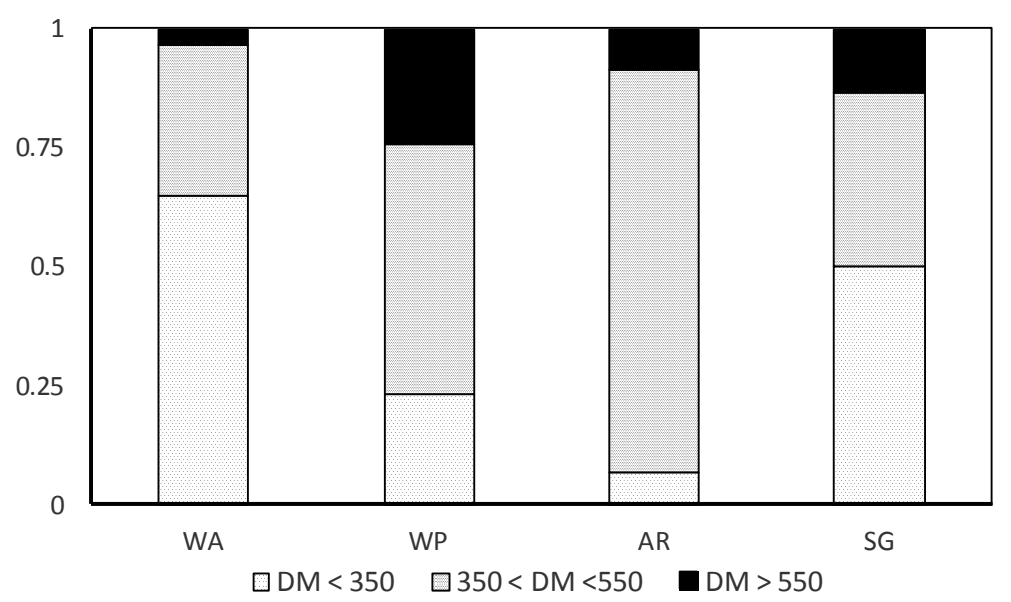

Figure 1. Frequency of commercially produced warm-season annual grass (WA), warm-season perennial grass (WP), annual ryegrass $(\mathrm{AR})$, and small grain (SG) silages of which dry matter (DM) concentration (DM g/kg) fell within DM $<350,350<\mathrm{DM}<550$, and $\mathrm{DM}>550$.

drying even when rain is not encountered, and accumulation of large quantities of forage. For WA silages at the lower DM extreme, either delaying harvest until a later stage of maturity or mechanically disrupting stems, as suggested by McCormick (2013), may enhance silage preservation. Van Soest (1982) noted that harvest of sorghum near maturity enhanced ensiling by the combination of fermentable carbohydrate levels and increased DM concentration to a range of 300 to $400 \mathrm{~g} / \mathrm{kg}$. Perhaps harvest of WA grasses for baleage at greater maturity than for chopped silage already occurs to some extent as suggested by the higher DM and higher fiber of baleage than chopped silage, although wilting of baleage also undoubtedly contributed to the higher DM. A similar difference in DM between baleage

Table 6. Correlation coefficient of nutritive value in producers' warm-season annual grass (WA), warm-season perennial grass (WP), annual ryegrass (AR), and small grain (SG) silage samples

\begin{tabular}{|c|c|c|c|c|c|}
\hline & TDN & $\mathrm{CP}$ & $\mathrm{DM}$ & $\mathrm{ADF}$ & NDF \\
\hline \multicolumn{6}{|l|}{ WA } \\
\hline TDN & 1 & $0.019^{\mathrm{ns}}$ & $0.187 *$ & $-0.982 * * *$ & $-0.845^{* * *}$ \\
\hline $\mathrm{CP}$ & & 1 & $0.092^{\mathrm{ns}}$ & $0.056^{\mathrm{ns}}$ & $0.097^{\mathrm{ns}}$ \\
\hline DM & & & 1 & $-0.153^{\mathrm{ns}}$ & $-0.096^{\mathrm{ns}}$ \\
\hline $\mathrm{ADF}$ & & & & 1 & $0.871 * * *$ \\
\hline NDF & & & & & 1 \\
\hline \multicolumn{6}{|l|}{ WP } \\
\hline TDN & 1 & $0.745 * * *$ & $0.015^{\mathrm{ns}}$ & $-0.996 * * *$ & $-0.758 * * *$ \\
\hline $\mathrm{CP}$ & & 1 & $-0.065^{\mathrm{ns}}$ & $-0.695 * * *$ & $-0.559 * * *$ \\
\hline $\mathrm{DM}$ & & & 1 & $-0.021^{\mathrm{ns}}$ & $0.074^{\mathrm{ns}}$ \\
\hline $\mathrm{ADF}$ & & & & 1 & $0.768 * * *$ \\
\hline NDF & & & & & 1 \\
\hline \multicolumn{6}{|l|}{ AR } \\
\hline TDN & 1 & $0.693 * * *$ & $0.113 * * *$ & $-0.977 * * *$ & $-0.879 * * *$ \\
\hline $\mathrm{CP}$ & & 1 & $-0.17626 * * *$ & $-0.528 * * *$ & $-0.580 * * *$ \\
\hline $\mathrm{DM}$ & & & 1 & $-0.185 * * *$ & $0.004^{\mathrm{ns}}$ \\
\hline $\mathrm{ADF}$ & & & & 1 & $0.870 * * *$ \\
\hline NDF & & & & & 1 \\
\hline \multicolumn{6}{|l|}{ SG } \\
\hline TDN & 1 & $0.75086^{* * *}$ & $0.29769^{\mathrm{ns}}$ & $-0.98654 * * *$ & $-0.87446^{* * *}$ \\
\hline $\mathrm{CP}$ & & 1 & $0.33445^{\mathrm{ns}}$ & $-0.63838 * *$ & $-0.61112 * *$ \\
\hline DM & & & 1 & $-0.26990^{\mathrm{ns}}$ & $-0.20639^{\mathrm{ns}}$ \\
\hline $\mathrm{ADF}$ & & & & 1 & $0.87547 * * *$ \\
\hline NDF & & & & & 1 \\
\hline
\end{tabular}

TDN, total digestible nutrient; CP, crude protein; DM, dry matter; ADF, acid detergent fiber; NDF, neutral detergent fiber; ns, not significant. $*, * *, * * *$, significant at $\mathrm{p}<0.05, \mathrm{p}<0.01$, and $\mathrm{p}<0.001$, respectively. 
and chopped silage of AR likely resulted primarily from wilting of baleage rather than harvest at greater maturity as indicated by the lower fiber concentrations of the baleage. The opposite result for DM of the two silage products from WP grasses may reflect a delayed harvest for chopped silage to provide a more substantial harvest volume. A more mature harvest stage for the WP grasses of both silage products than for silages of the other forage types is indicated by the higher $\mathrm{ADF}$ and NDF values for WP grasses. The other high fiber forage, chopped SG silage, appears to reflect a later maturity harvest for chopped silage than for baleage, which concurs with the previous report of increasing $\mathrm{ADF}$ and NDF with delayed harvest of SG forage (Juskiw et al., 2000). The DM levels of the two silage preparations, however, do not indicate such a difference, but the DM concentrations likely reflect the wilting of SG baleage which masks the actual forage DM at cutting. The high CP of SG baleage concurs with the fiber differences, suggesting that less mature SG was harvested as baleage. Edmisten et al. (1998) concluded that considering nutrient value and DM concentration at ensiling, harvest of small grain as silage should occur at the boot to hard dough stage when DM is 300 to $400 \mathrm{~g} / \mathrm{kg}$. While the mean DM of SG samples was within this range, the proportion of excessively wet samples was substantial. Harvesting SG for silage can be particularly difficult with the rapid morphological development which occurs a few weeks earlier than for AR while cool weather predominates. The opposite environmental conditions are encountered with WP grasses with hot sunny summer weather frequently hastening drying, although interspersed rainy humid weather often limits drying.

The measures of nutritive value provided for all forage samples, including silage, by the Louisiana State University Agricultural Center Forage Quality Lab fail to reflect effects of inadequate silage preservation. The measures of $\mathrm{ADF}$ and NDF largely reflect the forage quality at the time of harvest and indicate feeding value of adequately preserved silage. Deamination of amino acids during fermentation and particularly heat damage of digestible protein fractions of excessively dry silage alter the composition and digestibility of nitrogen compounds (Van Soest, 1982) reducing the usefulness of $\mathrm{CP}$ values of heat damaged silages. Han et al. (2006) reported that despite a steep increase in core temperature of alfalfa baleage that resulted in increased proportions of indigestible protein, CP values remained unchanged. A particular low DM concentration does not necessarily indicate heat damage but indicates an increased probability of heating (Van Soest, 1982). Both excessive DM and insufficient DM have been repeatedly identified with poor silage preservation (McDonald, 1981; Moisio and Heikonen, 1994). Lactic acid and lactic acid bacteria diffuse more slowly in drier silage than in wet silage, and unlike volatile fermentation endproducts, low moisture concentration can limit diffusion of aqueous phase pH change (Moisio and Heikonen, 1994). Lignin concentration and acid-detergent fiber nitrogen have been suggested as indicators of heat damaged silage (Van Soest, 1982) and would provide useful additional information. Silage quality of poorly preserved materials is often associated with palatability problems and low intake levels even when forage digestibility appears acceptable (Van Soest, 1982).

Moisture concentration appears to be a frequent limitation to silage quality in the south-central region, especially with forages other than AR. Although fermentation in heavily wilted forage can be weak and $\mathrm{pH}$ high, well sealed baleage of alfalfa (Medicago sativa) and perennial ryegrass (Lolium perenne) has maintained greater nutritive value than hay (Han et al., 2004; Han et al., 2006). The DM levels of silages other than AR in the south-central region suggest frequent unsuccessful ensiling attempts. Overcoming limitations of poorly preserved silage is not primarily related to silage testing and feeding strategies, but to improved efforts with the ensiling process itself primarily related to moisture level. Even properly ensiled forage of the WP grasses can generally be expected to have high fiber concentrations because maturity of these grasses at acceptable DM concentrations and yields is characteristically higher in fiber than the other forage types evaluated. The cool-season annuals, AR and SG, have potential to provide higher quality silages with superior CP and TDN when adequately preserved. Differences obtained between silage preparation approaches were not sufficient to determine that either chopped silage or baleage was a superior approach for silage production under the varied environmental conditions of the south-central USA, although baleage is readily amenable to wilting while direct-cut chopped silage is limited to the forage DM concentration at harvest.

\section{CONCLUSION}

Although the silage samples submitted in this evaluation were not a sampling to assess proportions of forage types commercially ensiled across the region, the sample proportions validly illustrate that $\mathrm{AR}$ is currently the primary forage stored as silage in the south-central USA. Annual ryegrass is the premier quality forage among those readily grown in the region, and this quality forage has been successfully stored as either chopped silage or baleage with a high frequency of success. The low proportion of samples with either excessive or insufficient DM indicates that control of DM (moisture level) at ensiling requires some attention. Several other forage species are harvested as silage in the region, however, each of these has limitations 
compared to AR. The earlier maturity of the somewhat similar SG species results in a more challenging harvest climate which increases risk of ensiling failure. Baleage offers the opportunity to increase DM concentration of this forage type and preserve high quality forage when the fleeting opportunity of infrequent sunny, low-humidity weather occurs in late winter. Warm-season grasses are lower in nutritive value than the cool-season grasses at harvest stages for silage. The large stems of the highly productive WA grasses provide distinct drying challenges under humid conditions, and energy from soluble carbohydrates can be depleted during fermentation under high summer temperatures reducing silage TDN levels. High yields of silage can be produced from the WA grasses, but ensiling risk and comparatively low nutritive value are aspects to consider with this forage type. The WP grasses can be expected to provide silage of high fiber concentration because the forage is mature and fibrous at silage harvest stage. The hot, humid weather at harvest provides challenges from both DM extremes, but with careful management and appropriate weather, rather lowcost silage can be produced from these perennial grasses.

\section{ACKNOWLEGMENTS}

The authors thank Randy Walz, Jerry Simmons, Laura Zeringue, and Tara Doughty for their technical assistance and maintaining the database.

\section{REFERENCES}

Bates, D. B., W. E. Kunkle, C. G. Chambliss, and R. P. Cromwell. 1989. Effect of dry matter and additives on bermudagrass and rhizome peanut round bale silage. J. Prod. Agric. 2:91-96.

Bremner, J. M. and G. A. Breitenbeck. 1983. A simple method for determination of ammonium in semimicro-Kjeldahl analysis of soils and plant materials using a block digester. Commun. Soil Sci Plant Anal. 14:905-913.

Collins, M. and V. N. Owens. 2003. Preservation of forage as hay and silage. In: Forages: An Introduction to Grassland Agriculture (Eds. R. F. Barnes et al.). Vol. 1. 6th Ed. Iowa State Press, Ames, IA, USA. pp. 443-471.

Edmisten, K. L., J. T. Green Jr., J. P. Mueller, and J. C. Burns. 1998. Winter annaul small grain forage potential. I. Dry matter yield in relation to morphological characteristics of four small grain species at six growth stages. Commun. Soil Sci. Plant Anal. 29:867-879.

Gordon, C. H., J. C. Derbyshire, W. C. Jacobson, and J. L. Humphrey. 1965. Effects of dry matter in low-moisture silage on preservation, acceptability, and feeding value for dairy cows. J. Dairy Sci. 48:1062-1068.

Han, K. J., M. Collins, E. S. Vanzant, and C. T. Dougherty. 2004. Bale density and moisture effects on alfalfa round bale silage. Crop Sci. 44:914-919.
Han, K. J., M. Collins, E. S. Vanzant, and C. T. Dougherty. 2006. Characteristics of baled silage made from first and second harvests of wilted and severely wilted forages. Grass Forage Sci. 61:22-31.

Haigh, P. M. 1990. Effect of herbage water-soluble carbohydrate content and weather conditions at ensilage on the fermentation of grass silages made on commercial farms. Grass Forage Sci. 45:263-271.

Henderson, A. R., J. M. Ewart, and G. M. Robertson. 1979. Studies on aerobic stability of commercial silage. J. Sci. Food Agric. 30:223-228.

Hersom, M. and W. E. Kunkle. 2011. Harvesting, storing, and feeding forages as round bale silage. Publication No. AN145. University of Florida, IFAS Extension, Gainesville, Fl, USA.

Huhnke, R. L., R. E. Muck, and M. E. Payton. 1997. Round bale silage storage losses of ryegrass and legume-grass forages. Appl. Eng. Agric.13:451-457.

Juskiw, P. E., J. H. Helm, and D. F. Salmon. 2000. Forage yield and quality for monocrops and mixtures of small grain cereals. Crop Sci. 40:138-147.

McCormick, M. 2013. Baled silage, uses for beef and dairy. In Proceedings of the 67th Southern Pasture and Forage Crop Improvement Conference. April 22-24, 2013; Tyler, TX, USA. pp. 12-15.

McDonald, P. 1981. The Biochemistry of Silage. Wiley-Blackwell, Chichester, New Yourk, USA.

Miller, W. J. and C. M. Clifton. 1965. Relation of dry matter content in ensiled material and other factors to nutrient losses by seepage. J. Dairy Sci. 48:917-923.

Moisio, T. and M. Heikonen. 1994. Lactic acid fermentation in silage preserved with formic acid. Anim. Feed Sci. Technol. 47:107-124.

Muck, R. E. and L. Kung, Jr. 2007. Silage production. pp. 617-633. In: Forages: the Science of Grassland Agriculture, Vol. II (Eds. R. F. Barnes, C. J. Nelson, K. J. Moore, and M. Collins). 6th ed. Blackwell Publishing, Ames, IA, USA.

Muck, R. E. and K. J. Shinners. 2001. Conserved forage (silage and hay): progress and priorities. In Proc. XIX Int. Grassland Congr., February 11-21, 2001. Sao Pedro, Sao Paulo, Brazil. http://naldc.nal.usda.gov/catalog/48355 (verified 5 Dec. 2013).

O'Brien, M., P. O. Kiely, P. D. Forristal, and H. T. Fuller. 2007. Visible fungal growth on baled grass silage during the winter feeding season in Ireland and silage characteristics associated with the occurrence of fungi. Anim. Feed Sci. Technol. 139:234-256

SAS Institute Inc. 2011. Base SAS 9.3 Procedure Guide: Statistical Procedures. SAS Institute Inc., Cary, NC, USA.

Van Soest, P. J. 1982. Nutritional Ecology or the Ruminant. O\&B Books, Inc., Corvallis, OR, USA.

Van Soest, P. J. and J. B. Robertson. 1980. Systems of analysis for evaluating fibrous feeds. In: Proc. Int. Workshop Standardization Analytical Methodology for Feeds. Int. Development Res. Ctr., Ottawa, Canada; March 12-14, 1979. Unipub, New York, USA. pp. 49-60. 